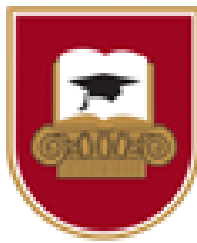

Vadyba

\title{
INDUSTRY DEVELOPMENT DURING CRISIS: THE CASE OF THE BREWER INDUSTRY IN CYPRUS, GREECE, IRELAND AND PORTUGAL
} (1)

\author{
Simeon Karafolas (2), Konstantinos Tsioras, Maria Papadopoulou, Antonia Farmouzi \\ University of Western Macedonia, Greece
}

(1) This paper presents some results of the research entitled "Development of productive activities during the period of the Greek crisis: the case of micro brewing in Greece" financed through the "Funding of Research Projects of the Special Research Account of the University of Western Macedonia".

Simeon Karafolas is the project manager.

(2) Corresponding author

\begin{abstract}
This article examines the evolution of brewing during the financial crisis on the basis of four countries, Cyprus, Greece, Ireland and Portugal. These countries asked for financial assistance and imposed restructuring programs that exacerbated the financial crisis. The examined period is extended from 2008 to 2017 and it is a period during which the adjustment programs were applied to these countries. The purpose of this article is to see if during the crisis an industry can have growth prospects. This search is based on the fact that during the crisis some countries or sectors or products can perform better than the whole. The examination was based on a comparative analysis between the four countries but also with the European Union countries considered as a whole. The paper focused on the comparative evolution regarding production, consumption, number of breweries and microbreweries and direct employment. The results showed that brewery production in the four countries was affected by the country's GDP growth. However it increased particularly in the second half of the period considered. This evolution was positively affected by the growth of tourism, especially in Greece and Portugal. The creation of breweries by small producers, especially in the second half of the period, is characteristic of the brewery's growth. New microbreweries have helped to create new jobs in countries with higher unemployment than the EU as a whole. KEY WORDS: Brewer industry; microbrewery; crisis; Cyprus; Greece; Ireland; European Union; Portugal.
\end{abstract}

\section{Introduction}

The crisis had several aspects such as financial, economic, productive and national. The crisis consequences have been different on national economies and productive sectors. Some countries suffered more from the crisis; an example is four European countries, Cyprus, Greece, Ireland and Portugal. Some sectors suffered from the important depression such as the case of construction in several countries and European regions. Other sectors had significantly better results such as the case of tourism in tourist regions and agriculture activities, (see for example the Greek case on tourism, Karafolas, 2018 and agriculture, Karafolas and Alexandrakis, 2015). The Economic crisis contributed to the professional transition either by migration abroad or internal migration. In the latter case, migration from large urban centers to the countryside is often associated with employment in agriculture and agro-tourism activities. One of these cases is the mid-2010 boom in microbrewery and the creation of microbreweries. The brewery industry and in particular microbrewery could be a pole for local development based on local production.

This article examines the development of the brewery industry in the period of the financial crisis. The investigation focuses especially in the four countries that asked for financial assistance from the European Bank, the European Commission and the International Monetary Fund (IMF) and applied adjustment programs agreed with their lenders. In 2010 and 2012 Greece received financial assistances, (European Commission 2018a); in 2011 Portugal asked for financial assistance, (European Commission 2018b), followed one year later, 2013, by two other countries, Cyprus, (European Commission 2018c), and Ireland, (European Commission 2018d). The economies of these countries had to face the global financial crisis but also their specific problems. We may note for example the public debt and public deficit in the case of Greece, (Karafolas, 2018) and in Portugal, (IMF, 2012); the involvement of Irish banks to enormous speculative exposures related to house

Vadyba / Journal of Management, Vol. 36, No. 1 2020, 53-60. 
loans, (Clarke and Hardiman, 2012); the consequence of Greek crisis to the Cypriot economy because of the involvement of Greek banks to Cypriot economy, (Karafolas, 2019), and Cypriot banks to the Greek economy.

The international financial assistance was followed in every one of these countries by stability measures that caused a major recession in the economy that resulted in the decline of the gross domestic product and the growth of unemployment, two of the main economic indicators examined in this investigation.

The paper focuses on a comparative examination of the brewery industry in order to investigate a sector that could present growth possibilities and perspectives during a period of economic decline. Furthermore, the microbrewery effect presents a particular interest due to its development in the decade of 2010. Thus, this investigation presents a scientific interest because, to our knowledge, this work is the first to present a comparative analysis of brewer industry during crisis and in particular between countries whose economy received financial assistance.

Brewery and in particular microbrewery has been the subject of studies examining the development of the local economy through rural and agro-tourism in general (see Everett, S. and C. Aitchison, 2008; Fox, 2014; Jakob, 2013) and the job prospects and entrepreneurship, (see Banks, 2010, Thurnell-Read, 2014). Other studies focused on country's case such as United Kingdom (Danson et al., 2015) and Quebec, (Blanchette, 2016).

After the introduction, section 2 presents the methodology and data followed by the results in section 3 and finally the conclusions.

\section{Methodology and data}

The examination isbased on a number of parameters that are production, consumption, number of active breweries and in particular breweries, as well as direct to the brewery industry employment. Between the examined countries, two of them have a similar population of 10 million, Greece and Portugal, while Ireland has half, 5 million; Cyprus is one of the less populated European Union (EU) countries of about 0, 9 million habitants. Consumer population however may grow considerably in several periods because of the tourism movement on long holidays or short-day tourism. Within these countries the beer consumption is not the same and it is due to the consumption habit. Consumption per capital is lower in Mediterranean countries compared to the EU-28 average; on the contrary it is higher in the case of Ireland, table 1.

Table 1. Beer consumption per capita, average of period 2008/2017, (in liters)

\begin{tabular}{lr} 
Country & Consumption \\
\hline Ireland & 84 \\
Cyprus & 53
\end{tabular}

\begin{tabular}{ll} 
Portugal & 51 \\
Greece & 36 \\
EU-28 & 72 \\
\hline
\end{tabular}

Source: The Brewers of Europe, 2018, and 2014 (author's calculations)

The examined period is from 2008 to 2017 . It begins at the global financial crisis and it includes the core of the financial and economic crisis of countries that asked for financial assistance and adopted austerity programs. For some of them and for most of the rest of EU-28 countries this period includes the post crisis period.

Through the evolution of the mentioned parameters between the examined countries and compared to the EU-28 countries the paper poses some questions. Are there similar or different characteristics in this evolution and what are they? During this period are there parameters that differentiate the countries? In order to have comparative data the main statistical source is provided by the Brewers of Europe. In some cases sources providing data on a specific country are used as well.

\section{Results}

\section{The evolution of production}

Considerable differences are observed regarding countries' production of beer through the example of EU countries of medium population, between 4 and 11 million, on the basis of the average production during the period 2008/2017, table 2. Ireland and Portugal approach the average of 13 countries that is 7,6 million hl, (hectoliter=100 liters). On the contrary Greek production is limited to 3, 9 million hl, which is one of the lowest productions in this period.

During the examined period, 2008/2017, the average of beer production presents a negative sign for all four countries and the total of EU-28 countries, table 3 . The negative sign is not the same during all the years of the period. It is negative in the beginning of the financial crisis for all examined cases. In particular for the four examined countries, it is negative during the periods that followed the agreement of financial assistance, table 3. The comparison of beer's production and this of gross domestic product, (GDP), table 4 , shows differences in the evolution of the two aggregates.

Table 2. Beer production of EU countries with medium population *, average of period 2008/2017, (in $1.000 \mathrm{hl}$ $* *)$

\begin{tabular}{lr}
\hline Country & Production \\
\hline Czech Republic & 19.153 \\
Belgium & 18.864 \\
Austria & 8.978 \\
Ireland & 8.060 \\
Average of 13 countries & 7.627 \\
Portugal & 7.518 \\
Hungary & 6.316
\end{tabular}


Social sciences, Industry Development During Crisis: the Case of the Brewer Industry in Cyprus, Greece, Ireland and Portugal

\begin{tabular}{lll}
\hline Denmark & 6.203 & Cyprus*** \\
Bulgaria & 4.996 & Source: as table 1 \\
Sweden & 4.631 & $*$ Population between 4 and 11 million habitants. \\
Finland & 4.136 & ** hl: Hectoliter is a metric unit of volume equal to 100 \\
Greece & 3.896 & liters. \\
Croatia & 3.531 & purpose \\
Slovakia & 2.875 &
\end{tabular}

Table 3. Annual evolution of beer production, (in \%)

\begin{tabular}{lrrrrrrrrrr}
\hline Country & 2009 & 2010 & 2011 & 2012 & 2013 & 2014 & 2015 & 2016 & 2017 & $\begin{array}{r}\text { Average } \\
2017 / 08\end{array}$ \\
\hline Cyprus & $-10,1$ & $-4,5$ & $-7,6$ & 4,8 & $-2,1$ & $-1,2$ & 7,2 & 7,0 & 4,9 & $-0,2$ \\
Greece & $-7,2$ & $-5,7$ & $-6,1$ & 1,2 & 0,1 & $-1,3$ & 3,2 & 0,2 & $-0,7$ & $-1,8$ \\
Ireland & $-9,1$ & 2,6 & 3,2 & $-3,7$ & $-2,3$ & $-9,0$ & 6,4 & $-1,0$ & 4,4 & $-0,9$ \\
Portugal & $-4,6$ & 6,1 & $-0,2$ & $-3,8$ & $-8,3$ & $-0,5$ & $-11,3$ & 0,1 & 8,0 & $-1,6$ \\
Total EU 28 & $-3,8$ & $-1,5$ & 1,4 & $-0,6$ & $-0,8$ & 0,2 & 1,6 & 0,6 & 0,2 & $-0,3$ \\
\hline
\end{tabular}

Source: As table 1

Note: compared to previous year

Table 4. Annual evolution of gross domestic product, (in \%)

\begin{tabular}{lrrrrrrrrrrr}
\hline & 2008 & 2009 & 2010 & 2011 & 2012 & 2013 & 2014 & 2015 & 2016 & 2017 & $\begin{array}{r}\text { Average } \\
2008 / 17\end{array}$ \\
\hline Cyprus & 3,6 & $-2,0$ & 1,3 & 0,4 & $-2,9$ & $-5,8$ & $-1,3$ & 2,0 & 4,8 & 4,5 & 0,5 \\
Greece & $-0,3$ & $-4,3$ & $-5,5$ & $-9,1$ & $-7,3$ & $-3,2$ & 0,7 & $-0,4$ & $-0,2$ & 1,5 & $-2,8$ \\
Ireland & $-4,5$ & $-5,1$ & 1,8 & 0,3 & 0,2 & 1,4 & 8,6 & 25,2 & 3,7 & 8,1 & 4,0 \\
Portugal & 0,2 & $-3,0$ & 1,9 & $-1,8$ & $-4,0$ & $-1,1$ & 0,9 & 1,8 & 1,9 & 2,8 & 0,0 \\
EU-28 & 0,5 & $-4,3$ & 2,1 & 1,7 & $-0,4$ & 0,3 & 1,8 & 2,3 & 2,0 & 2,5 & 0,8 \\
\hline
\end{tabular}

Source: The World Bank, 2019 (author's calculations)

Note: compared to previous year

In the case of EU-28 an almost similar evolution is observed even if the GDP has a higher growth during all the examined years. An analogous evolution is presented for the Irish case for which GDP has a higher growth compared to beer production, tables 3 and 4 . For the other countries differences on the evolution of both aggregates are more obvious. In the Greek and Cypriot cases the beer production follows a higher growth compared to the GDP in the second half of the examined period, which is during the period of the application of the adjustment programs, tables 3 and 4 . This could predict development potentialities of beer production in both cases. Higher fluctuations of beer production compared to this of GDP are observed in the Portuguese case. By the end of the period, the growth on beer production replaced a period of long decline; we note that GDP's growth had begun two years earlier, tables 3 and 4 .

The tourism effect is not negligible at all, especially in this period. Especially in the Greece and Portuguese and less for Ireland an important growth on arrivals appears the time period 2013-2018, table 5 .

n/a.: Not available
Table 5. Number of arrivals in tourist accommodation, (in millions)

\begin{tabular}{rrrrr}
\hline & Cyprus & Greece & Ireland & Portugal \\
\hline 2006 & 2,3 & 14,0 & 8,0 & 13,1 \\
2007 & 2,3 & 16,0 & 8,3 & 14,0 \\
2008 & 2,3 & 16,0 & 8,0 & 14,4 \\
2009 & 2,3 & 20,9 & 7,2 & 14,1 \\
2010 & 2,4 & 20,6 & 7,1 & 14,5 \\
2011 & 2,5 & 21,1 & 7,6 & 14,9 \\
2012 & 2,5 & 18,2 & 7,6 & 14,6 \\
2013 & 2,4 & 20,1 & 8,3 & 15,9 \\
2014 & 2,4 & 21,8 & 8,8 & 17,9 \\
2015 & 2,3 & 24,1 & 9,5 & 19,8 \\
2016 & 2,7 & 25,0 & 10,1 & 21,9 \\
2017 & 3,0 & 26,1 & n/a & 24,6 \\
2018 & 3,2 & 28,7 & n/a & 25,9 \\
\hline
\end{tabular}

Source: a/ Statista, 2019: cases of Cyprus, Greece and Portugal, b/ CEIC, 2019: case of Ireland, (author's calculations) 
The comparative analysis shows important margins for growth in all cases. Two parameters that can help to better understand potentialities of production are the evolution of consumption and the number of breweries created.

\section{Does production volume cover the countries demand for consumption?}

Table 6 presents the production volume compared to consumption for every one of the examined cases. One has to note that while production volume refers to the domestic one, the demand for consumption may covered partly by imports. Production volume is higher to consumption for
EU-28 countries and it is much higher in the case of Ireland and Portugal, table 6. On the contrary production volume is significantly lower to consumption demand in the case of Cyprus. In the Greek case production almost covers the demand for consumption. In both, Greek and Cypriot cases a significant part of consumption demand is covered by local production the last years of the examined period, table 6.

This evolution shows the potentialities of beer production in both countries.

One question rises through this evolution; is this evolution related to a growth of production units or even new companies?

Table 6. Percentage of beer production volume to beer consumption volume, (in \%)

\begin{tabular}{lcccccccccc}
\hline Country & 2008 & 2009 & 2010 & 2011 & 2012 & 2013 & 2014 & 2015 & 2016 & 2017 \\
\hline Cyprus & 90 & 74 & 66 & 69 & 70 & 67 & 75 & 75 & 78 & 74 \\
Greece & 98 & 96 & 96 & 90 & 95 & 96 & 96 & 100 & 99 & 100 \\
Ireland & 170 & 166 & 171 & 180 & 175 & 185 & 163 & 176 & 168 & 179 \\
Portugal & 132 & 128 & 141 & 156 & 162 & 148 & 153 & 136 & 132 & 133 \\
Total EU-28 & 108 & 108 & 109 & 109 & 109 & 110 & 110 & 110 & 110 & 111 \\
\hline
\end{tabular}

Source: As table 1 (author's calculations)

\section{The evolution of breweries}

The number of active breweries grew considerably during the examined period for the EU-28 countries, table 7; it grew in the second half of the period on a much higher level for the three examined countries, Greece, Ireland and especially Portugal, table 7.

Table 7. Number of active breweries

\begin{tabular}{lrrrrrrrrrrr}
\hline Country & 2008 & 2009 & 2010 & 2011 & 2012 & 2013 & 2014 & 2015 & 2016 & $\begin{array}{r}\text { Average } \\
2017\end{array}$ \\
$\begin{array}{l}\text { growth } \\
2008 / 17\end{array}$ \\
\hline Cyprus & 2 & 2 & 2 & 2 & 2 & 2 & 4 & 4 & 3 & 3 & $8,3 \%$ \\
Greece & 11 & 11 & 11 & 17 & 18 & 20 & 20 & 28 & 43 & 43 & $18,3 \%$ \\
Ireland & 26 & 26 & 26 & 26 & 26 & 30 & 50 & 64 & 93 & 102 & $18,3 \%$ \\
Portugal & 7 & 7 & 7 & 7 & 9 & 18 & 35 & 64 & 94 & 120 & $42,3 \%$ \\
Total EU-28 & 3.454 & 3.714 & 3.988 & 4.393 & 5.081 & 5.770 & 6.528 & 7.410 & 8.501 & 8.350 & $10,4 \%$ \\
\hline
\end{tabular}

Source: As table 1 (author's calculations)

This evolution was influenced by the creation of microbreweries, table 8 . While at the beginning of the examined period for Greece and Portugal no microbrewery is mentioned, since 2011 their number multiplied. In Portugal, the number of microbreweries grew from 0 in 2010 to 115 in 2017 and in Greece from
7 in 2011 to 30 in 2017, table 8. An analogous phenomenon is observed in Ireland that had already a significant number of microbreweries. The creation and development of microbreweries contributed to the observed growth of beer production during the last years of the examined period. 
Social sciences, Industry Development During Crisis: the Case of the Brewer Industry in Cyprus, Greece, Ireland and Portugal

Table 8. Number of microbreweries

\begin{tabular}{|c|c|c|c|c|c|c|c|c|c|c|c|}
\hline Country & 2008 & 2009 & 2010 & 2011 & 2012 & 2013 & 2014 & 2015 & 2016 & 2017 & $\begin{array}{l}\text { Average } \\
\text { growth } \\
2011 / 17\end{array}$ \\
\hline Cyprus & $\mathrm{n} / \mathrm{a}$ & $\mathrm{n} / \mathrm{a}$ & $\mathrm{n} / \mathrm{a}$ & 0 & 0 & 0 & 2 & 2 & 1 & 1 & $-5,6 \%$ \\
\hline Greece & $\mathrm{n} / \mathrm{a}$ & $\mathrm{n} / \mathrm{a}$ & $\mathrm{n} / \mathrm{a}$ & 7 & 8 & 9 & 10 & 15 & 25 & 30 & $19,4 \%$ \\
\hline Ireland & 15 & 17 & 20 & 24 & 29 & 40 & 60 & 76 & 99 & 105 & $19,1 \%$ \\
\hline Portugal & 0 & 0 & 0 & 1 & 3 & 12 & 30 & 60 & 89 & 115 & $91,9 \%$ \\
\hline Total EU-28 & 1.755 & 2.123 & 2.407 & 2.670 & 3.094 & 3.616 & 4.626 & 5.225 & 6.433 & 6.998 & $11,7 \%$ \\
\hline
\end{tabular}

Source: As table 1 and Shawn Day, 2018 (author's calculations)

n/a: Not available

During the growth of microbreweries the growth of investments is observed for the four countries. After a long period of decline, in 2104 , investments growth begun for Ireland and Portugal; it followed in the next years for Cyprus and Greece, table 9. The growth of investments in the case of microbreweries was financed through several forms. Beyond the traditional ways of financing investment, self-financed and banking financing, other forms related to public financing or non-banking financing tools are used. Funds from European Union and national programs are one of these tools. The European Regional Development Fund financed projects related to small beer craft as in the case of the UK, (Beach, 2019). European and national programs lunched through specific programs as the Rural Development Program and the Community Led Local development/LEADER (Liaison Entre Actions de Développement de l' Economie Rurale -Links between actions for the development of the rural economy) that are interested on the rural activities, (National Rural network, 2018). An interesting case presents the financing through crowd funding; Mac an Bhaird et all. (2019) examined the financing of Irish craft brewers through the crowd funding platforms.

Table 9. Annual evolution of gross fixed capital formation (investments), (in \%)

\begin{tabular}{cccccccccc}
\hline & 2009 & 2010 & 2011 & 2012 & 2013 & 2014 & 2015 & 2016 & 2017 \\
\hline Cyprus & $-15,3$ & $-0,4$ & $-13,5$ & $-20,1$ & $-15,7$ & $-11,8$ & 0,6 & 48,9 & 26,1 \\
Greece & $-14,3$ & $-19,6$ & $-20,4$ & $-23,6$ & $-9,0$ & $-6,1$ & $-0,6$ & 3,9 & 9,2 \\
Ireland & $-22,9$ & $-18,0$ & $-3,6$ & 21,1 & $-2,9$ & 20,6 & 57,3 & 53,1 & $-3,7$ \\
Portugal & $-9,1$ & $-0,6$ & $-12,2$ & $-17,9$ & $-5,6$ & 3,4 & 7,2 & 3,6 & 13,8 \\
\hline \multicolumn{7}{c}{ Source: Eurostat, 2019, (author's calculations) }
\end{tabular}

\section{Consequences on the employment}

Has the growth of breweries influenced the employment in this industry? The creation of new companies produces new jobs. The question that is raised is on the consequences overall in the brewery industry. Before we answer the question two parameters have to be mentioned; a/The brewery industry is mostly capital intense and consequently creates less jobs compared to labor-intensive industry; b/Any employment effect of this industry must be compared to the unemployment of the economy for every examined case. The table 10 presents the annual unemployment rate in the five examined cases the same period.

Table 10. Annual Unemployment rate, (in \%)

\begin{tabular}{rrrrrr}
\hline \multicolumn{2}{c}{ Cyprus } & Greece & Ireland & Portugal & EU-28 \\
\hline 2008 & 3,7 & 7,8 & 6,8 & 8,8 & 6,4 \\
2009 & 5,4 & 9,6 & 12,6 & 10,7 & 9,0 \\
2010 & 6,3 & $\mathbf{1 2 , 7}$ & 14,6 & 12,0 & 10,2 \\
2011 & 7,9 & 17,9 & 15,4 & $\mathbf{1 2 , 9}$ & 10,1 \\
2012 & 11,9 & 24,5 & 15,5 & 15,8 & 10,8
\end{tabular}




\begin{tabular}{rrrrrr}
2013 & $\mathbf{1 5 , 9}$ & 27,5 & $\mathbf{1 3 , 8}$ & 16,4 & 11,2 \\
2014 & 16,1 & 26,5 & 11,9 & 14,1 & 10,5 \\
2015 & 15,0 & 24,9 & 10,0 & 12,6 & 9,6 \\
2016 & 13,0 & 23,6 & 8,4 & 11,2 & 8,7 \\
2017 & 11,1 & 21,5 & 6,7 & 9,0 & 7,6 \\
2018 & 8,4 & 19,3 & 5,8 & 7,0 & 6,6 \\
\hline \multicolumn{5}{r}{ Source: Eurostat, 2019a, (author's calculations) }
\end{tabular}

The unemployment rate of the four examined countries is higher, even double in some cases, compared to the average of EU-28. In the four countries unemployment grew considerably in the periods following the adjustments programs. Only by the end of the examined period notable decline of unemployment is observed; although it remains higher than the average of EU-28, except Ireland on 20082017, table 10.

Table 11 presents the number of employees working directly in breweries; the data does not include related sectors such as agriculture offering the raw material for brewing. The total of EU-28 direct employment declined by $1,1 \%$ over the examined period, mainly in the first half of the period that is during and just after the global financial crisis, table 11. For two countries, Cyprus and Ireland, a notable decline of direct employment is observed, especially at the end of the period. In two other countries, Greece and Portugal, the microbrewery effect permitted the growth of direct employment. In the Greek case this effect has an additional importance because of the high unemployment rate in the country, table 10.

Table 11. Direct employment to brewery industry on 2008-2017 (rounded to units 100) and average growth of the period (in \%)

\begin{tabular}{lrrrrrrrrrrr}
\hline Country & 2008 & 2009 & 2010 & 2011 & 2012 & 2013 & 2014 & 2015 & 2016 & 2017 & $\begin{array}{r}\text { Average } \\
\text { evolution } \\
2017 / 08 *\end{array}$ \\
\hline Cyprus & 0,8 & 0,8 & 0,8 & 0,7 & 0,6 & 0,6 & 0,6 & 0,6 & 0,6 & 0,6 & $-3,0 \%$ \\
Greece & 1,8 & 1,9 & 1,9 & 1,9 & 1,9 & 1,9 & 1,9 & 2 & 2 & 2 & $1,2 \%$ \\
Ireland & 1,8 & 1,9 & 1,9 & 1,6 & 1,5 & 2 & 2 & 1,7 & 1,4 & 1,1 & $-4,1 \%$ \\
Portugal & 1,5 & 1,5 & 1,5 & 1,5 & 1,4 & 1,5 & 2,1 & 1,9 & 2,1 & $\mathrm{n} / \mathrm{a}$ & $5,2 \%$ \\
Total EU- 28 & 138 & 131 & 129 & 128 & 125 & 124 & 126 & 122 & 122 & 125 & $-1,1 \%$ \\
\hline
\end{tabular}

Source: as Table 1 (author's calculations)

* For Portugal the average is the period of 2016/08

n/a: Not available

\section{Conclusions}

This paper examines the brewery industry during the crisis period and in particular in four countries that faced the consequences of adjustment programs following the financial assistance, Cyprus, Greece, Ireland and Portugal. The question was if in these specific countries economic consequences could lead to the search for new investment opportunities. The examination was based on some parameters that were the evolution of brewery production and consumption on the one hand and on the other hand the evolution of the number of breweries and the consequences in employment. A comparative analysis between four countries and the total of EU-28 countries could help to better understand the examined issues. Further, evolution of production and employment would be better understood when compared to the GDP growth and unemployment. A main conclusion on the beer production is that it is influenced by the evolution of GDP and it presents a strong growth in the four examined countries by the end of the examined period, since 2015 for the three and 2014 for Portugal; the same period investments increased significantly. The growth in this specific period is much higher compared to the total of EU-28 countries. For Greece and Portugal the parameter of tourism seems to have a positive effect especially after 2014 . The growth of beer production permitted in the Greek case to cover the consumption by its national production as in the case of Ireland and Portugal. The second half of the examined period the huge growth of microbreweries is observed, especially for Portugal, Ireland and Greece. This growth offered new jobs. The employment effect is very important to the examined countries that had unemployment rates much higher compared to the EU28 average in the examined period.

The paper shows overall an interest of producers to the small brewery industry. A policy favoring this interest should have positive effects by growing the 
employment. Policies of facilitating the financing of small craft industries should have positive results. Creation of clusters between these craft industries could facilitate the entry on the national market as well. The creation of a kind of "Beer Roads" should facilitate the access and knowledge to microbreweries.

\section{References}

Bank of Greece, 2014, The chronicle of great crisis the Bank of Greece 2008-2013, https://www.bankofgreece.gr > Publications

Banks, M., 2010, "Craft labour and creative industries", International journal of cultural policy, 16(3), 305-321.

Beach, A., 2019, ERDF finances local craft beer production in the Outer Hebrides, https://ec.europa.eu/regional_policy/en/newsroom/n ews/2019/10/23-10-2019-erdf-finances-local-craftbeer-production-in-the-outer-hebrides (received on March 25, 2020)

Blanchette, J., 2016, "Les micro-brasseurs du Québec : étude de la réalité d'une communauté d'artisans créatifs", HEC, Montreal, Canada.

CEIC, 2019, Ireland Tourism Statistics, Number of International arrivals, https://www.ceicdata.com/en/ireland/tourismstatistics (received on March 26, 2020)

Clarke, B., and Hardiman, N., 2012, Crisis in the Irish banking System, Geary Working paper 2012/03

Danson, M., Galloway, L., Cabras I., and T. Beatty, 2015, "Microbrewing and entrepreneurship: The origins, development and integration of real ale breweries in the UK", The International Journal of Entrepreneurship and Innovation, 16(2), 135-144.

European Commission, 2018a, Financial assistance to Greece https://ec.europa.eu/info/business-economyeuro/economic-and-fiscal-policy-coordination/eufinancial-assistance/which-eu-countries-havereceived-assistance/financial-assistancegreece_en\#secondeconomicadjustmentprogrammef orgreece (received on September 24, 2019)

European Commission, 2018b, Financial assistance to Portugal, https://ec.europa.eu/info/businesseconomy-euro/economic-and-fiscal-policycoordination/eu-financial-assistance/which-eucountries-have-received-assistance/financialassistance-portugal_en (received on September 24, 2019)

European Commission, 2018c, Financial assistance to Cyprus, https://ec.europa.eu/info/businesseconomy-euro/economic-and-fiscal-policycoordination/eu-financial-assistance/which-eucountries-have-received-assistance/financialassistance-cyprus_en (received on September 24, 2019)

European Commission, 2018d, Financial assistance to Ireland, https://ec.europa.eu/info/businesseconomy-euro/economic-and-fiscal-policycoordination/eu-financial-assistance/which-eucountries-have-received-assistance/financial-
These issues could be the object of further research. Further investigations would be on the incentives of small producers to the brewery industry and the sustainable development potential in every examined country.

assistance-

ireland_en\#economicadjustmentprogrammeforirela nd (received on September 14, 2019)

Eurostat, 2019, Statistics, Gross fixed capital formation, annual data, https://ec.europa.eu/eurostat/tgm/table.do?tab=table \&init $=1 \&$ language $=$ en $\&$ pcode $=$ tec $00011 \&$ plugin $=1$ (received on March 25, 2019)

Eurostat, 2019a, Statistics, Unemployment rate annual data,

https://ec.europa.eu/eurostat/databrowser/view/tipsu n20/default/table?lang=en (received on September 24, 2019)

Everett, S. and C. Aitchison, 2008, "The role of food tourism in sustaining regional identity: A case study of Cornwall, South West England", Journal of Sustainable Tourism, 16(2),150-167.

Fox, S., 2014, "Third Wave Do-It-Yourself (DIY): Potential for prosumption, innovation, and entrepreneurship by local populations in regions without industrial manufacturing infrastructure", Technology in Society, 39, 18-30.

IMF, 2011, Portugal: Request for a Three-Year Arrangement Under the Extended Fund Facility, Country Report No. 11/127

Jakob, D., 2013, "Crafting your way out of the recession? New craft entrepreneurs and the global economic downturn", Cambridge Journal of Regions Economy and Society, 6(1), 127-140.

Karafolas, 2019, Greek banks abroad, an Historic examination, in Nicos Sykianakis, N., Polychronidou, P. and A.Karasavvoglou, (Editors), Economic and Financial Challenges for Eastern Europe, Springer Proceedings in Business and Economics , ISBN 978-3-030-12168-6 ISBN 9783-030-12169-3 (eBook), pp. 149-160. https://doi.org/10.1007/978-3-030-12169-3

Karafolas, S., 2018, "Effects of economic crisis: a regional examination based on touristic regions in Greece“, Vadyba/Journal of Management, 32(1), 81-89. ISSN 1648-7974

Karafolas, S. and A. Alexandrakis, 2015, "Unemployment effects of the Greek crisis: a regional examination", Procedia Economics and Finance, 19, 82-90.

Mac an Bhaird, C., Owen, R. Drakopoulou Dodd, S., Wilson, J and A. Bisignano, 2019, Small beer? Peer-to-peer lending in the craft beer sector, Strategic Change, 2019;28:59-68, https://doi.org/10.1002/jsc.2246

National Rural network, 2018, Rural Development Programme of Greece 2014-2020 and Community 
Led Local development/LEADER, https://ead.gr/home-en/leader_clld-en/ (received on March 26, 2020)

Shawn Day, 2018, Microbreweries Over Timehttp://shawnday.com/ (received on September 26, 2019)

Statista, 2019, Number of arrivals in tourist accommodation from 2006 to 2018; Cyprus, Greece, Portugal, https://www.statista.com/statistics/413230/numberof-arrivals-spent-in-short-stay-accommodation
The Brewers of Europe, 2018, "Beer statistics, 2018 edition"

The Brewers of Europe, 2014, "Beer statistics, 2014 edition"

The World Bank, 2019, World Bank national accounts, data, GDP annual, The World Bank, https://data.worldbank.org/indicator/ny.gdp.mktp.k d.zg (received on September 10, 2019)

Thurnell-Read, T., 2014, "Craft, tangibility and affect at work in the microbrewery", Emotion Space and Society, 13 , 46-54.

\section{RECEIVED: 15 November 2019}

ACCEPTED: 14 May 2020

Simeon Karafolas, Phd, professor of Accounting and Finance Department, Faculty of Economics Sciences, University of Western Macedonia, Greece. Prof. S. Karafolas is the Director of a Master program on Banking and Finance at the same university. He is author of articles, monographies and books on banking, finance, cooperatives, immigration, regional development. He received two European Union grants for post-doc researches and participated to two INTERREG projects on financing of SMEs. Scientific interests: banking, finance, cooperatives, immigration and regional development. E-mail karafola@teiwm.gr and skarafola@yahoo.gr

Konstantinos Tsioras is lecturer of Accounting and Finance Department, Faculty of Economics Sciences, University of Western Macedonia, Greece He has a MSc in Computer Science with Applications, Aston University, Birmingham, UK. His interests are on Enterprise Resource Planning Systems and computer application methods. Email ktsioras@teiwm.gr

Maria Papadopoulou is graduated on Accounting and on Finance; she has a MSc on Accounting and Finance at the University of Aberysthwyth, Wales, UK. She gives courses at the Department of Accounting and Finance at the University of Western Macedonia, Greece. Email mariapapa169@gmail.com

Antonia Farmouzi is graduated on Accounting and Finance and has a MSc on Banking and Finance at the University of Western Macedonia, Greece. She is the author of two graduate theses on marketing of agriculture products. Email antoniafarmouzi@yahoo.gr 